\title{
Effects of ship-breaking activities on the abundance and diversity of macrobenthos in Sitakundu Coast, Bangladesh
}

\author{
JAHANARA AKHTER LIPI ${ }^{1}$, MD. ABU NOMAN ${ }^{2}$, M. BELAL HOSSAIN ${ }^{1, \bullet}$, ABU HENA MUSTAFA KAMAL ${ }^{3}$, \\ MOHD. HANAFI IDRIS ${ }^{3}$ \\ ${ }^{1}$ Department of Fisheries and Marine Science, Noakhali Science and Technology University. Sonapur, Noakhali-3814, Bangladesh. \\ Tel./fax.: +880-321-71484, `email: mbhnstu@gmail.com \\ ${ }^{2}$ College of Marine and Environmental Science, Tianjin University of Science and Technology. 13th Avenue, No. 29, TEDA, Tianjin, PR China \\ ${ }^{3}$ Faculty of Fisheries and Food Science, Universiti Malaysia Terengganu. 21030 Kuala Nerus, Terengganu, Malaysia
}

Manuscript received: 20 August 2020. Revision accepted: 8 October 2020.

\begin{abstract}
Lipi JA, Noman MDA, Hossain MB, Abu Hena MK, Idris MH. 2020. Effects of ship-breaking activities on the abundance and diversity of macrobenthos in Sitakundu Coast, Bangladesh. Biodiversitas 21: 5085-5093. To articulate the ecological processes or anthropogenic impacts, it is necessary to explore various distributional patterns of benthic communities. The study was conducted to investigate the variability of macrobenthos between a ship braking and non-ship-breaking area along the Sitakunda coast, Chittagong, Bangladesh. This is the first comprehensive study that addresses the effects of ship-breaking activities on the variability of benthic communities in the study area. Macrobenthos were sampled from two different regions namely Bhatiary (ship-breaking area) and Banshbaria (non-ship-breaking area/reference area) in two different time periods (April and July) for comparative analyses. During the study period, Polychaeta was the most dominant group comprising $60 \%$ of the total macrobenthos all over the study area. Macrobenthos abundance and diversity demonstrated strong spatial variability. The mean abundance varied from $3799.75 \pm 3452.28$ ind. $/ \mathrm{m}^{2}$ to 4107.25 \pm 2743.6 ind. $/ \mathrm{m}^{2}$ from the ship-breaking to non-ship-breaking area. Similar to macrobenthos abundance, the diversity index $\left(H^{\prime}\right)$ (varied between 2.45 and 1.85), species richness (D) (varied between 1.99 and 1.04), and the number of taxa (varied between 17.25 and 9.25) were higher in the non-ship-breaking area compared to the ship-breaking area. Multivariate analyses, nMDS, and CCA plot showed a distinct grouping for different location. Besides, the diversity indices of the Polychaeta community, and the presence or absence of several pollution indicator taxa revealed that Bhatiary (the ship-breaking area) was confronting deleterious effects of ship-breaking activities.
\end{abstract}

Keywords: Macrobenthos, rainfall, ship-breaking activities, Sitakundu coast, spatial distribution

\section{INTRODUCTION}

Seashore comprises the majority of the macrobenthic species (Herman et al. 1999; Mulik et al. 2020) and those species play a vital role in food web by forming a major link between primary producers and higher trophic levels while regulating organic matter decomposition and nutrient cycling (Lin et al. 2020). Macrobenthic invertebrate species are known as ecosystem engineers because they continuously influence the physical parameters, the flow of waters, and changing the environments (Gogina and Zettler 2010). They provide a linkage among substratum, seabed, and water column predators (Gray and Elloitt 2009). All living beings, microscopic to macroscopic, assume a tremendous job in adjusting the biological system. Loss or extinction of any assemblages of living beings hampers the functioning of that biological system (Hossain et al. 2013). Benthic communities are often used as biological indicators because they can provide information on environmental condition either due to the sensitivity of single species (indicator species) or because of some general feature that makes them integrate environmental signals over a long period of time (Tagliapietra et al. 2010; Netto et al. 2018). Biological hazard analysis is necessary for scientifically authentic assessment of the environment. This way may contribute to the conservation and the regulation of nature from anthropogenic affects (Chen et al. 2013). By knowing these, macrobenthos has become the subject of many studies all over the world even in Bangladesh.

The south-eastern coastal area of Bangladesh is highly productive and possesses a huge amount of marine and coastal resources. In recent years, this area is losing its norm because of different anthropogenic factors and industrial pressure. Ship-breaking, repairing, demolition, and various kinds of related activities are increasing severely in this area. Ship-breaking and Repairing Industries (SBRI) are key sources of cheap iron and steel, for construction and other development purposes. In most of the developing countries, ship-breaking activities are currently carried out and the level of activity in Bangladesh is $23 \%$ in terms of light displacement ton (LTD) from 1994 to 2009 (NCSG 2011; Abdullah et al. 2013). But, the matter of fact that SBRIs are strong sources of hazardous contaminants along the coastal seashore, which is the most, diversified area of the world. Unfortunately, in comparison with other studies, ship-breaking activities and its impact on the coastal zone received very lower attention from the previous researchers of Bangladesh. But, this area plays a significant role in the country's economy. Besides, a huge portion of the country's total fisheries production comes from this area every year. Though there are many types of research on the benthic community, diversity and 
abundance (Khan et al. 2007; Hossain et al. 2009; Asadujjaman et al. 2012; Abu Hena et al. 2013; Hossain et al. 2013; Islam et al. 2013), a very few research (Sarker et al. 2016) held on the assessment of pollution, and there are no records of research on this issue in Sitakundu.

Therefore, by considering the knowledge gap and importance of macrobenthos and their habitat, the present investigation was undertaken to set baseline information on the spatiotemporal variability of macrobenthos community between a ship-breaking area and a non-ship-breaking area (reference area) along the Sitakundu coast of Bangladesh. Using the variability of macrobenthos diversity indices and several indicator taxa, this study may provide preliminary information about macrobenthos and habitat condition for the future research to study the in-depth deleterious effect of ship-breaking activities in this area.

\section{MATERIALS AND METHODS}

\section{Study area}

The study areas were separated into ship-breaking area and reference area for comparative analysis of macrobenthos abundance (Figure 1). The ship-breaking area namely Bhatiary and non-ship-breaking area namely Banshbaria along Sitakundu coast. According to (YPSA 2005) there are 24 ship-breaking yards in this area and the area extending from over $14 \mathrm{~km}$ along this area and more than 100 companies are involved in the ship-breaking business (YPSA 2011). Two sampling locations from shipbreaking area (L1, L2) and two from the reference area (L3 and L4) were selected during April and June in 2016 (Table 1). Three replicate samples were collected from the intertidal area at each station to determine the physical parameters and macrobenthos abundance.

\section{Sample collection}

Intertidal sediments were collected during the low tide period using a mud corer having a mouth area of $0.01 \mathrm{~m}^{2}$. In order to ensure the data accuracy, three replicate samples were collected from each station. Collected sediments diluted gently in the water, and the residues retained by sieving through a 500- $\mu \mathrm{m}$ mesh size net. Collected residues were promptly preserved in $10 \%$ formalin solution and transferred to the laboratory. To enhance the visibility of benthic fauna, a modest quantity of "Rose Bengal" (2-3 ml from a solution of $200 \mathrm{mg}$ Rose Bengal/ $\mathrm{L}^{-1}$ distilled water) was added to the sediment sample in the laboratory. Benthic fauna was identified as the lowest possible taxon through an optical microscope (Model No. XSZ 21014DN, China) according to the characteristics described by Al-Yamani et al. (2012). Meanwhile, the identified fauna was quantified and calculated as the total number of inds. $/ \mathrm{m}^{2}$. Water temperature $\left({ }^{\circ} \mathrm{C}\right)$, salinity (psu), and $\mathrm{pH}$ were measured using Centigrade thermometer, Refractometer (INDEX, Model no. REF201) and Digital pen $\mathrm{pH}$ meter (HANNA Instrument, Model No. H-196107).

Table 1. Study area and the coordinates of sampling locations

\begin{tabular}{lcll}
\hline Name of area & $\begin{array}{c}\text { Sampling } \\
\text { location }\end{array}$ & Latitude & Longitude \\
\hline Ship-breaking & L1 & $22^{\circ} 23^{\prime} 58.4^{\prime \prime} \mathrm{N}$ & $91^{\circ} 44^{\prime} 28.2^{\prime \prime} \mathrm{E}$ \\
area (Bhatiary) & L2 & $22^{\circ} 25^{\prime} 56.64^{\prime \prime} \mathrm{N}$ & $91^{\circ} 43^{\prime} 47.64^{\prime \prime} \mathrm{E}$ \\
Reference area & L3 & $22^{\circ} 32^{\prime} 24.2^{\prime \prime} \mathrm{N}$ & $91^{\circ} 39^{\prime} 56.4^{\prime \prime} \mathrm{E}$ \\
(Banshbaria) & L4 & $22^{\circ} 32^{\prime} 54.5^{\prime \prime} \mathrm{N}$ & $91^{\circ} 39^{\prime} 52.1^{\prime \prime} \mathrm{E}$ \\
\hline
\end{tabular}

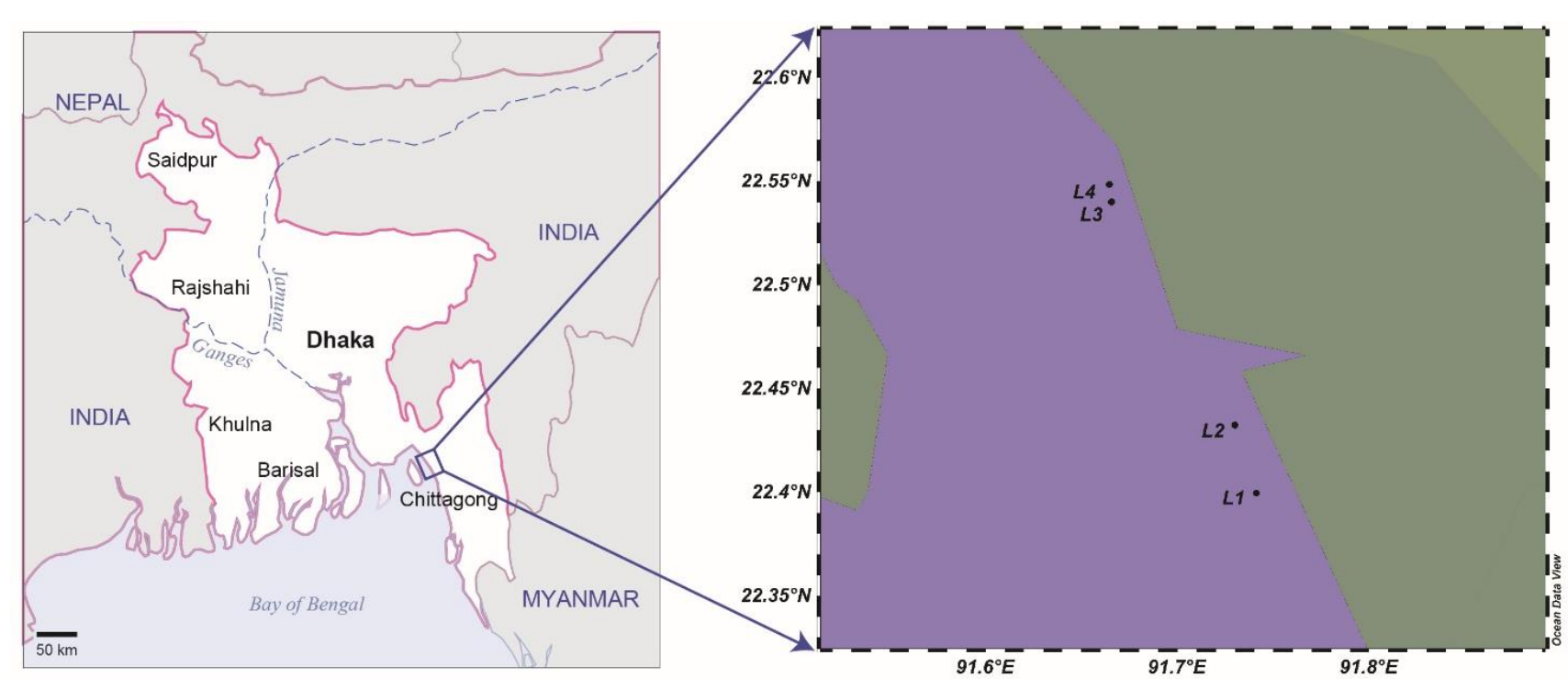

Figure 1. Map of Sitakundu Coast, Bangladesh showing sampling locations. L1 and L2 indicates ship-breaking area and L3 and L4 indicates reference area 


\section{Data analysis}

After counting each group of macrofauna, total abundance, mean abundance, and standard error (SE) were calculated from the estimates of each replicate sample from respective station. Macrofaunal diversity, evenness, and richness were discerned using the Shannon-Wiener index $\left(H^{\prime}\right)$, Pielou's evenness index $\left(\mathrm{J}^{\prime}\right)$, and Margalef's richness index (D) respectively. Square root transformed BrayCurtis similarity-based non-metric multidimensional scaling (nMDS) with visualizing cluster overlay (with all replicate samples) was analyzed through PRIMER software (Version 6). In addition, Canonical Correspondence Analysis (CCA) was performed to show the relationship between species composition and physical factors using Past v 3.0 software.

\section{RESULTS AND DISCUSSION}

\section{Physical parameters}

The physical parameters seem more or less similar in the ship-breaking and reference area. The water temperature varied from $28.33-30.3^{\circ} \mathrm{C}$ in the ship-breaking area and 31.67 to $35.33^{\circ} \mathrm{C}$ in the reference area. It was found that the $\mathrm{pH}$ of the examining area was alkaline in nature wherein it was practically similar in most of the stations bearing a range of $8-8.8$ in the ship-breaking area and 8.03-9.8 in the reference area. Besides, the salinity also didn't show much variability between these two areas. But, salinity showed a notable variation in two different sampling periods. Because of heavy rainfall and surface runoff, the salinity ranged from 0.33 to $0.67 \mathrm{psu}$ in June, whereas in April it ranged between 10.17-10.67 psu in both areas. Similarly, the higher water temperature was estimated during the April (average temperature $31.62 \pm 3.34^{\circ} \mathrm{C}$ ) and lower during June (average temperature $31.06 \pm 1.01^{\circ} \mathrm{C}$ ) (Figure 2).

\section{Variability of macrobenthos distribution}

The macrofauna of the present study was identified to family. In the ship-breaking area, a sum of 15 taxa (families) of benthic fauna found during the study, whereas a total of 27 taxa of benthic fauna were identified from the reference area. The current study yielded an aggregate of 15432 inds. $/ \mathrm{m}^{2}$ with an average abundance of
$3799.75 \pm 3452.28$ inds. $/ \mathrm{m}^{2}$ from all stations of shipbreaking area. On the other hand, a total number of 16429 inds. $/ \mathrm{m}^{2}$ of macrobenthos were recovered from all stations of the reference area with an average abundance of 4107.25 \pm 2743.6 inds. $/ \mathrm{m}^{2}$. However, the abundance of macrobenthic fauna demonstrated a notable variability between the sampling period. The average abundance in April was around five folds higher than June bearing $6541.67 \pm 1292.25$ and $1275.00 \pm 736.04$ inds. $/ \mathrm{m}^{2}$ respectively.

Seven major groups of macrobenthos were identified from the entire study. The composition of macrobenthic assemblage didn't show much variability between the shipbreaking and non-ship-breaking areas (Figure 3). Polychaeta was the prevailing group in both regions. At the ship-breaking area, Polychaeta contained $60 \%$ of total macrobenthos and followed by Bivalvia and Decapoda bearing $32 \%$ and $5 \%$ respectively (Figure 3). In the reference area, the group Polychaeta also indicated similar distribution bearing $62 \%$ of total abundance and followed by Amphipoda (16\%) and Bivalvia (11\%) (Figure 3). Capitellidae and Psammobidae dominated the shipbreaking area contributing $34 \%$ and $31 \%$ respectively whereas Nephtyidae and Hyperidae were the dominant taxa at the reference area contributing $11.76 \%$ and $11.16 \%$ respectively.

\section{Variability of macrobenthos diversity indices}

Diversity indices showed significant differences between the areas. During the study period, higher values of diversity indices were observed in April while in June the diversity was lower. The number of taxa, S-W diversity index, and Margalef's species richness showed much variability between two regions. The number of taxa shifted from 21 to 14 at the reference area while it ranged from 10 to 8 at the ship-breaking area. The diversity was higher as well in this area. The diversity value changed from 2.49 to 2.55 at the reference, whereas at the shipbreaking area it varied from 1.5 to 1.85 . Similarly, the Margalef's species richness value depicted that the richness was lower at the ship-breaking area than the reference area. The species richness ranged from 1.68 to 2.29 in the reference area while at the ship-breaking area the richness varied from 0.99 to 1.11 (Table 2).
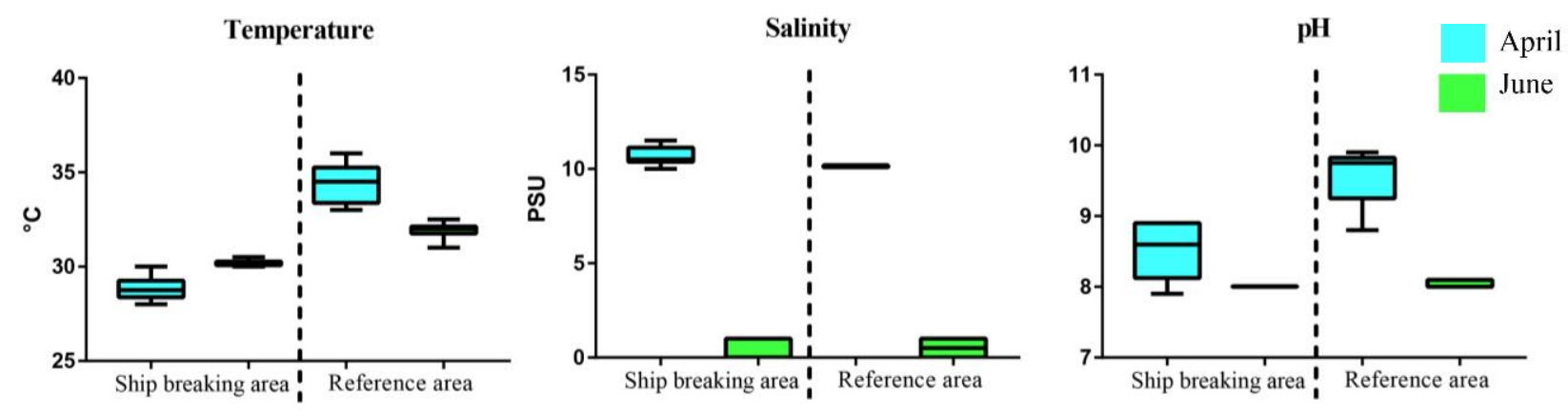

Figure 2. Distribution of physicochemical parameters in the study area, Sitakundu Coast, Bangladesh, during April and June 
Table 2. Diversity indices examined from the ship-breaking and reference area in both seasons (A-April; J-June)

\begin{tabular}{lcccccccc}
\hline \multirow{2}{*}{ Diversity indices } & \multicolumn{4}{c}{ Ship-breaking area } & \multicolumn{3}{c}{ Reference area } \\
\cline { 2 - 10 } & AL1 & AL2 & JL1 & JL2 & AL3 & AL4 & JL3 & JL4 \\
\hline Taxa (S) & 10 & 11 & 8 & 8 & 21 & 2.52 & 2.55 & 2.26 \\
Shannon $\left(H^{\prime}\right)$ & 1.69 & 1.5 & 1.84 & 1.85 & 0.59 & 0.67 & 0.68 & 2.49 \\
Evenness $(J)$ & 0.54 & 0.41 & 0.79 & 0.79 & 2.29 & 2.05 & 1.68 & 1.97 \\
Margalef (D) & 1.06 & 1.11 & 1.018 & 0.99 & & &
\end{tabular}

A

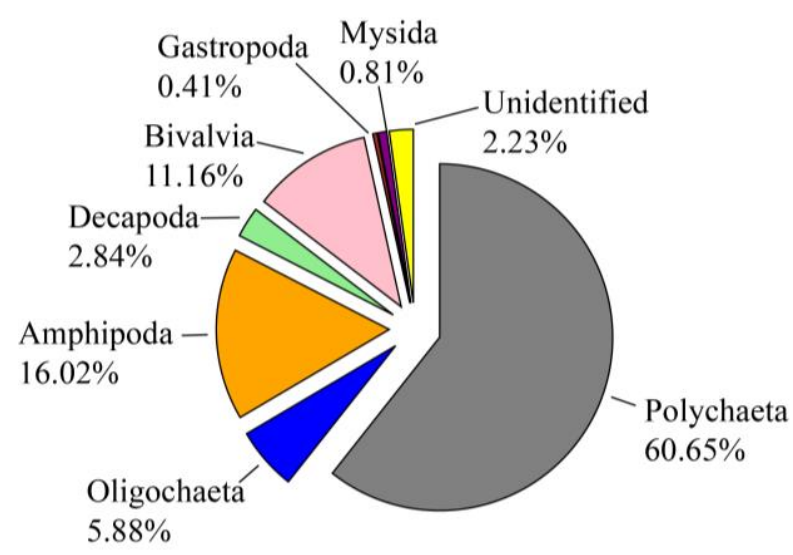

B

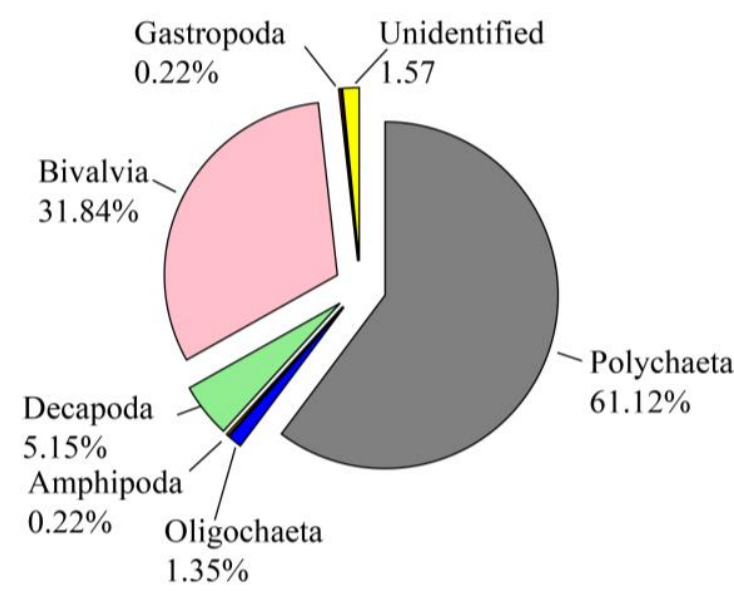

Figure 3. Percentage composition of the macrobenthic groups in both the reference (A) and ship-breaking area (B)

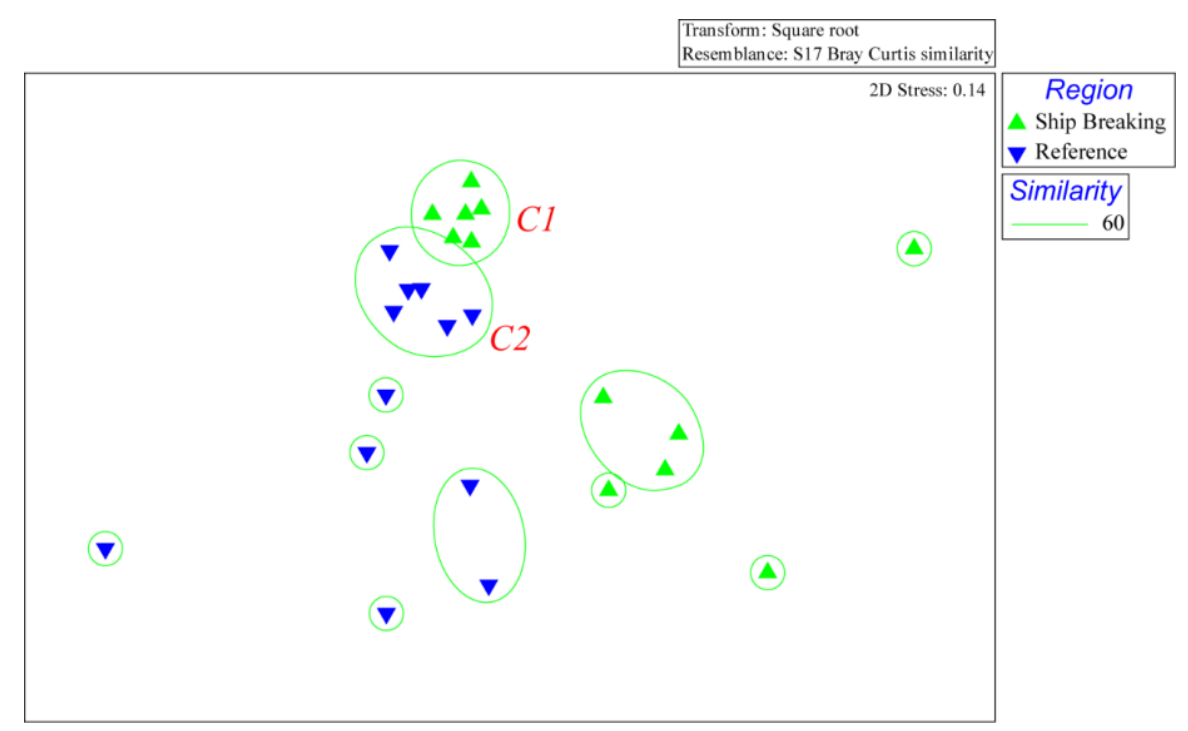

Figure 4. nMDS plot with overlying cluster showing the clustering of samples in different areas and different seasons

\section{Relationship between macrobenthos and physical parameters}

The nMDS plot is showing the cluster of all the samples from the whole study. At a $60 \%$ degree of similarity all the samples from the ship-breaking and reference area showed distinct grouping with each other. Two major clusters were found at $60 \%$ similarity, which is indicated as C1 and C2 in Figure 4. Most of the samples from the reference area made a distinct cluster (C2). Similarly, the samples from the ship-breaking area made a different cluster (C1). However, from the nMDS plot, it is clearly visible that there was significant variability between two regions (Figure 4). 
CCA analysis between the physical parameters and taxa composition revealed that salinity was the most significant factor $(P<0.05)$ in this study. CCA triplot was projected from the first two axes of CCA, which comprises respectively $68.3 \%$ and $31.7 \%$ of the samples. From the CCA plot, four groups of taxa were differentiated based on the taxa distribution and their relationship with physical parameters (Figure 5). The group 'A' taxa were positively correlated with temperature and those were mainly distributed in reference area (L3, L4) during April. All the stations during June comprised similar species composition and segregated in group 'B'. Those taxa were positively correlated with temperature and negatively correlated with salinity and $\mathrm{pH}$. Capitellidae and Psammobidae were highly abundant in the ship-breaking area during April and showed a negative relationship with temperature (Group C). Some of the macrobenthic taxa didn't show any relationship with the physical parameters (Group D). However, it is observed from the CCA analysis that macrobenthic taxa composition differs from the region based on their preferred environmental parameter. Though species composition was almost similar in both of the area during June, it differs in April and non-ship-breaking area was a promoter in this aspect.

\section{Pollution indicator groups}

Different groups of polychaete have been used for assessing the overall "health" of the benthic community (Dean 2008). Among them, the capitellids (such as Capitella capitate) act as the positive indicator of the detrimental environment, which means their presence reveals the poor environmental condition (Dean 2008; Belan 2013). On the other hand, members of the family Lumbrinidae, Maldanidae, Sabellidae, and Terebellidae negatively respond to the harmful condition, that means, their absence denotes the poor environmental condition (Belan 2003; Olsgard et al. 2003; Dean 2008). We observed, both the positive indicators and the negative indicators showed similar distribution in the reference and ship-breaking area during June. However, in April, maximum abundance of Capitellidae recovered from the ship-breaking area, which was several times higher than the reference area (Table 3, Figure 6). Besides, the negative indicators Lumbrinidae, Maldanidae, Sabellidae and Terebellidae were also found in the reference area during April.

\section{Discussion}

A total of 28 taxa of macrobenthic fauna were identified during the study period comprising 15 taxa from the shipbreaking area and 27 taxa from the reference area. Seven major groups of macrobenthos were identified wherein Polychaeta was the most dominant group comprising more than $60 \%$ of the total macrobenthos on an average. It is evident from most of the regional macrobenthos study that Polychaeta dominated this area all the year round (Khan et al. 2007; Asadujjaman et al. 2012; Noman et al. 2018). The abundance of macrobenthos was much higher in April $\left(6541.67 \pm 1292.25\right.$ inds. $\left./ \mathrm{m}^{2}\right)$ in this area than June $\left(1275 \pm 736.04\right.$ inds. $\left./ \mathrm{m}^{2}\right)$.

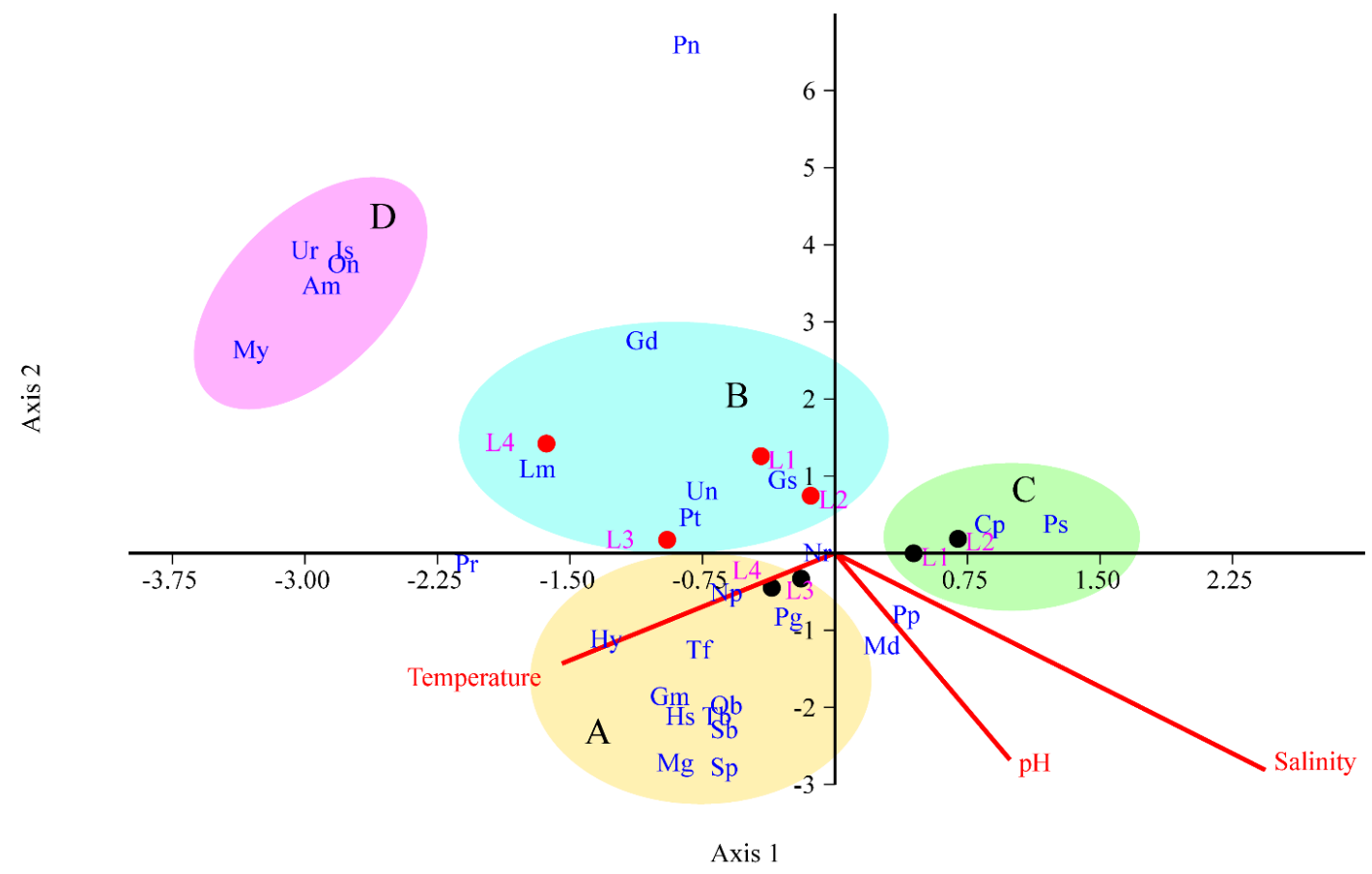

Figure 5. CCA triplot showing the relation between station, environment and macrobenthos. (black dots- April, red dots- June; AmAmpeliscidae; Ps-Psammobidae; Cp-Capitellidae; Pt-Portunidae; Gm-Gammaridae; Gs-Gastropod larvae; Gd-Goniadidae; HsHesionidae; Hy-Hyperidae; Is-Isaeidae; Lm-Lumbrinereidae; Mg-Magelonidae; Md-Maldanidae; My-Mysidae; Np-Nephtyidae; NrNereididae; On-Onuphidae; Ob-Orbiniidae; Pr-Paraonidae; Pn-Penaeidae; Pg-Pilargiidae; Pp-Priapulidae; Sb-Sabellidae; Sp-Spionidae; Tb-Terebellidae; Tf-Tubificidae; Ur-Urothoidae; Un-Unidentified) 
Table 3. Macrobenthic taxa (ind./ $\mathrm{m}^{2}$ ) identified from the present study

\begin{tabular}{|c|c|c|c|c|c|c|c|c|c|c|}
\hline Name of taxa & AL1 & AL2 & AL3 & AL4 & JL1 & JL2 & JL3 & JL4 & Mean & $\mathbf{S E}$ \\
\hline Ampeliscidae & 0.00 & 0.00 & 0.00 & 0.00 & 0.00 & 0.00 & 33.33 & 100.00 & 16.67 & 12.60 \\
\hline Capitellidae & 2233.33 & 2500.00 & 500.00 & 866.67 & 266.67 & 200.00 & 233.33 & 33.33 & 854.17 & 342.49 \\
\hline Gammaridae & 0.00 & 0.00 & 333.33 & 66.67 & 0.00 & 33.33 & 0.00 & 0.00 & 54.17 & 40.79 \\
\hline Gastropod larvae & 0.00 & 33.33 & 33.33 & 0.00 & 0.00 & 0.00 & 0.00 & 33.33 & 12.50 & 6.10 \\
\hline Goniadidae & 0.00 & 0.00 & 0.00 & 66.67 & 66.67 & 0.00 & 0.00 & 33.33 & 20.83 & 10.80 \\
\hline Hesionidae & 0.00 & 0.00 & 66.67 & 100.00 & 0.00 & 0.00 & 0.00 & 0.00 & 20.83 & 14.00 \\
\hline Hyperidae & 0.00 & 0.00 & 733.33 & 833.33 & 0.00 & 0.00 & 233.33 & 100.00 & 237.50 & 122.87 \\
\hline Isaeidae & 0.00 & 0.00 & 0.00 & 0.00 & 0.00 & 0.00 & 0.00 & 166.67 & 20.83 & 20.83 \\
\hline Lumbrinereidae & 0.00 & 66.67 & 466.67 & 533.33 & 200.00 & 266.67 & 566.67 & 133.33 & 279.17 & 77.14 \\
\hline Magelonidae & 0.00 & 0.00 & 33.33 & 0.00 & 0.00 & 0.00 & 0.00 & 0.00 & 4.17 & 4.17 \\
\hline Maldanidae & 33.33 & 133.33 & 166.67 & 200.00 & 0.00 & 0.00 & 0.00 & 0.00 & 66.67 & 30.21 \\
\hline Mysidae & 0.00 & 0.00 & 0.00 & 0.00 & 0.00 & 0.00 & 100.00 & 33.33 & 16.67 & 12.60 \\
\hline Nephtyidae & 233.33 & 366.67 & 700.00 & 700.00 & 33.33 & 0.00 & 466.67 & 66.67 & 320.83 & 100.78 \\
\hline Nereididae & 333.33 & 366.67 & 400.00 & 566.67 & 100.00 & 100.00 & 66.67 & 0.00 & 241.67 & 71.20 \\
\hline Onuphidae & 0.00 & 0.00 & 0.00 & 0.00 & 0.00 & 0.00 & 0.00 & 33.33 & 4.17 & 4.17 \\
\hline Orbiniidae & 0.00 & 0.00 & 33.33 & 100.00 & 0.00 & 0.00 & 0.00 & 0.00 & 16.67 & 12.60 \\
\hline Paraonidae & 0.00 & 0.00 & 100.00 & 33.33 & 0.00 & 0.00 & 133.33 & 0.00 & 33.33 & 18.90 \\
\hline Penaeidae & 0.00 & 0.00 & 0.00 & 0.00 & 66.67 & 33.33 & 0.00 & 0.00 & 12.50 & 8.77 \\
\hline Pilargiidae & 133.33 & 166.67 & 300.00 & 366.67 & 0.00 & 0.00 & 33.33 & 100.00 & 137.50 & 48.16 \\
\hline Portunidae & 100.00 & 100.00 & 66.67 & 100.00 & 0.00 & 0.00 & 133.33 & 33.33 & 66.67 & 17.82 \\
\hline Priapulidae & 900.00 & 733.33 & 366.67 & 1000.00 & 0.00 & 0.00 & 133.33 & 0.00 & 391.67 & 150.76 \\
\hline Psammobidae & 800.00 & 3700.00 & 1466.67 & 300.00 & 0.00 & 233.33 & 66.67 & 0.00 & 820.83 & 448.01 \\
\hline Sabellidae & 0.00 & 0.00 & 33.33 & 33.33 & 0.00 & 0.00 & 0.00 & 0.00 & 8.33 & 5.46 \\
\hline Spionidae & 0.00 & 0.00 & 33.33 & 0.00 & 0.00 & 0.00 & 0.00 & 0.00 & 4.17 & 4.17 \\
\hline Terebellidae & 0.00 & 0.00 & 33.33 & 133.33 & 0.00 & 0.00 & 0.00 & 0.00 & 20.83 & 16.59 \\
\hline Tubificidae & 200.00 & 0.00 & 266.67 & 533.33 & 0.00 & 0.00 & 133.33 & 33.33 & 145.83 & 66.05 \\
\hline Urothoidae & 0.00 & 0.00 & 0.00 & 0.00 & 0.00 & 0.00 & 0.00 & 33.33 & 4.17 & 4.17 \\
\hline Unidentified & 100.00 & 33.33 & 133.33 & 100.00 & 33.33 & 66.67 & 33.33 & 100.00 & 75.00 & 13.73 \\
\hline
\end{tabular}

Note: A: April; J: June; L: Location; SE: standard error
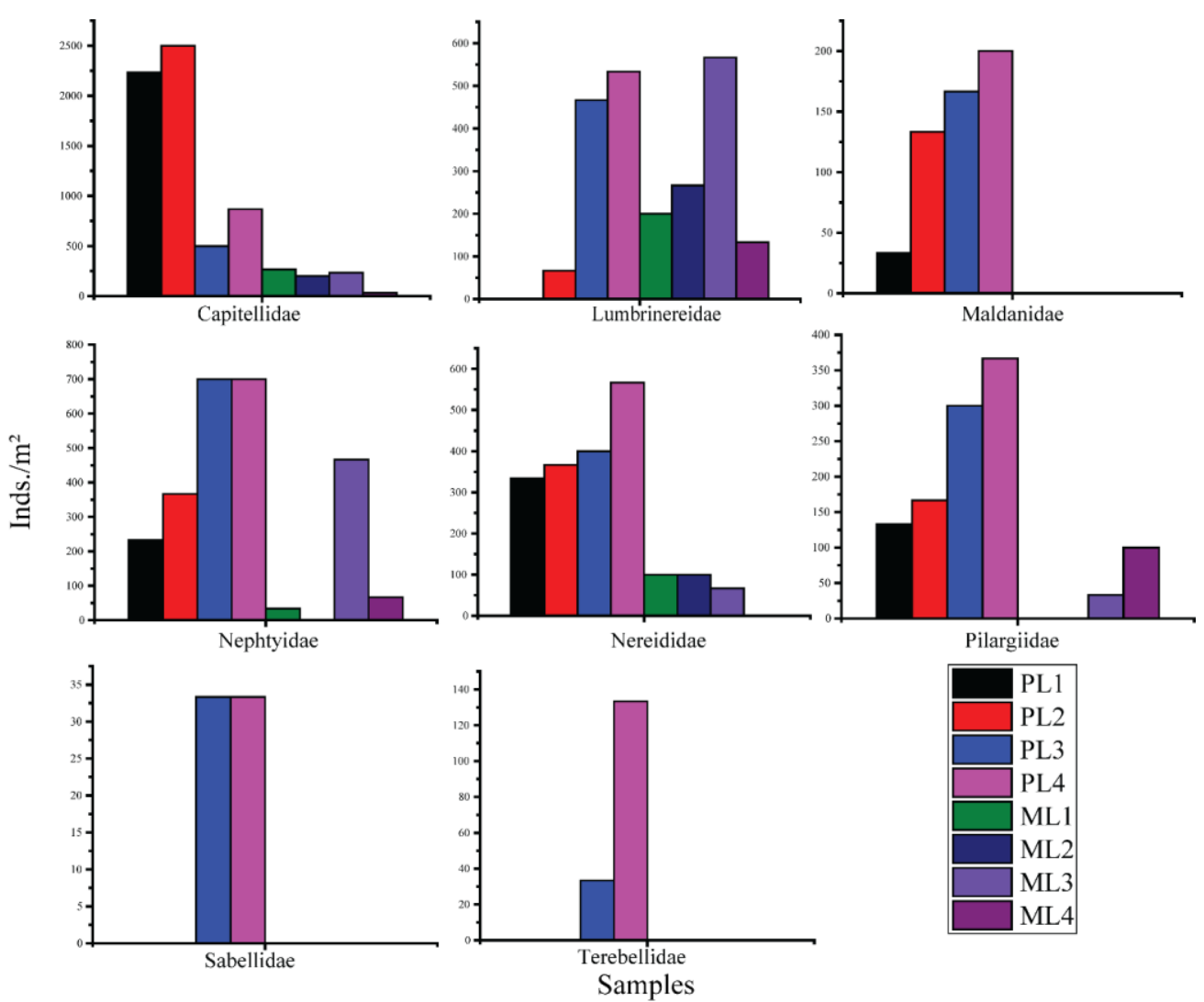

Figure 6. Variability of macrobenthic indicator taxa in the present study 
Similarly, the number of taxa and macrobenthos diversity $\left(H^{\prime}\right)$ was also maximum during April. It was reported that macrobenthos abundance decreases in the monsoon because of rainfall (Hossain et al. 2009). In this region, the monsoon starts with the month of June and the amount of rainfall is relatively higher. Our CCA analysis showed that salinity was the major factor for the variation of abundance between two sampling periods, which revealed the effects of low salinity causing terrestrial runoff and rainfall over macrobenthos community. In association with these findings, most of the regional studies demonstrated that rainfall influences the macrobenthos community (Hossain 2009; Kumar and Khan 2013; Noman et al. 2018).

The mean abundance of macrobenthos was higher in the reference area than the ship-breaking area bearing respectively $4107.25 \pm 2743.6 \quad$ inds. $/ \mathrm{m}^{2}$ and $3799.75 \pm 3452.28$ inds. $/ \mathrm{m}^{2}$. The diversity indices values were higher at the reference area than the ship-breaking area. The S-W diversity index value at the ship-breaking area varied from 1.49 to 1.85 while in the reference area it was higher and ranged between 2.48 to 2.55 . Noman et al. (2018) found the $\mathrm{S}-\mathrm{W}$ index ranged from 1.05 to 1.67 while Khan et al. (2007) reported that the diversity varied from $1.20 \pm 0.23$ to $1.49 \pm 0.753$. Similarly, Hossain et al. (2013) observed in Hatiya and Nijhum Dweep island diversity fluctuated from 1.22 to 1.49 . Most of the studies showed that the S-W index value didn't show much variability in their findings, whereas we observed significant differences of S-W index within the two-study area. Similarly, the species richness value was also higher in the reference area. There are supposed to be a noteworthy change in benthic community parameters especially their abundance, biomass, dominance and diversity, when the community experience stress due to harmful environmental condition (Dean 2008). Therefore, we hypothesized, the shipbreaking area was influenced by deleterious materials, which might have lowered the abundance, diversity, and richness of macrobenthos in this area. Besides, Sarker et al. (2016) reported the species richness varied from $2.21 \pm 0.43$ to $1.36 \pm 0.11$ respectively in less polluted Bakkhali estuary and extremely polluted Meghna estuary, which supports our findings and the prediction. The presence or absence of macrofauna and variability of diversity indices (Rodrigues et al. 2017) especially S-W diversity index, species evenness index ( $\mathrm{Li}$ et al. 2018), and species richness (Margalef 1958) can be a measure of pollution over benthic community.

Moreover, the Polychaeta community can act as a significant ecotoxicological testing component because of their short life cycle, smaller size, and substantial contribution to any benthic community (Dean 2008). We observed the diversity indices of Polychaeta community varied greatly between ship-breaking area and reference area. Higher abundance, number of taxa, diversity, and richness of Polychaeta recorded in the reference area. However, in June, all these indices were almost similar in both areas (Figure 7). However, it's a challenging task to assign a specific benthic species as the indicator of deteriorated condition. Different geographical settings react differently to detrimental ecological conditions possessing their own arrangement of positive indicators and negative indicators (Dean 2008). In the Sitakundu coast, we found high abundance of Nephtyidae, Nerididae, and Pilargiidae in the reference area, which might be the negative indicators of pollution in this area (Figure 6). However, the response of indicator taxa and their seasonal variation supports our hypothesis that the benthic community of the ship-breaking area was confronting severe unsettling and deleterious effects, and the rainfall in June alleviated the detrimental effect of ship-breaking activities.

Besides, at the $60 \%$ similarity levels the entire cluster showed the distinct grouping of regions. Cluster C1 included the samples from the ship-breaking area while the cluster C2 showed the grouping of the reference area. Sampling stations of different zones forming distinguished groups elucidate the alteration in species composition and abundance (Pravinkumar et al. 2013; Khan et al. 2017). However, similar to the nMDS analysis, CCA triplot also showed that all samples from the June accumulated on the same axis. Besides, based on our findings from CCA analysis, salinity is a significant factor shaping the species composition, which depicted that rainfall might have alleviated the detrimental effect of ship-breaking activities. But, we couldn't identify any specific factor, which was significantly responsible for the variation of macrobenthos between ship-breaking area and reference area. Therefore, it can be predicted from our study that the physical factors were not responsible for the variation of macrobenthos abundance, diversity, and richness between the reference area and the ship-breaking area. There must be other factors, which influenced the abundance of macrobenthos in the ship-breaking area.

This is might be the effects of various kinds of abnormalities produced by the ship-breaking activities in this area. Hossain and Islam (2006) found that elevated turbidity, total suspended solids, and total dissolved solids reflect the physical disturbance in the ship-breaking area. According to Siddiquee (2004); Apeti et al. (2012), during ship-breaking exercises trace metals, are yielded and discharged results increased concentrations with respect to permissible values or standard limits. Shipyard soil reported to be contaminated with hazardous radioactive materials such as radium (226Ra), thallium (232Th), and potassium $(40 \mathrm{~K})$ due to shoreline ship-breaking activities (Hossain et al. 2010). Moreover, ship-breaking activities also affect the availability of organic materials in the soil (Rubaiyat et al. 2013). All these combined factors might be the possible reason for the low abundance of macrobenthos in the ship-breaking area (Siddiquee 2004). Because of resource limitation, we couldn't include the organic and inorganic pollutants in our study. Therefore, we cannot precisely hypothesize which pollutants were responsible for the low abundance of macrobenthos in the ship-breaking. Hence, further research is recommended in this area including all the pollutants to find out the toxicological effects of ship-breaking on macrobenthic community. 

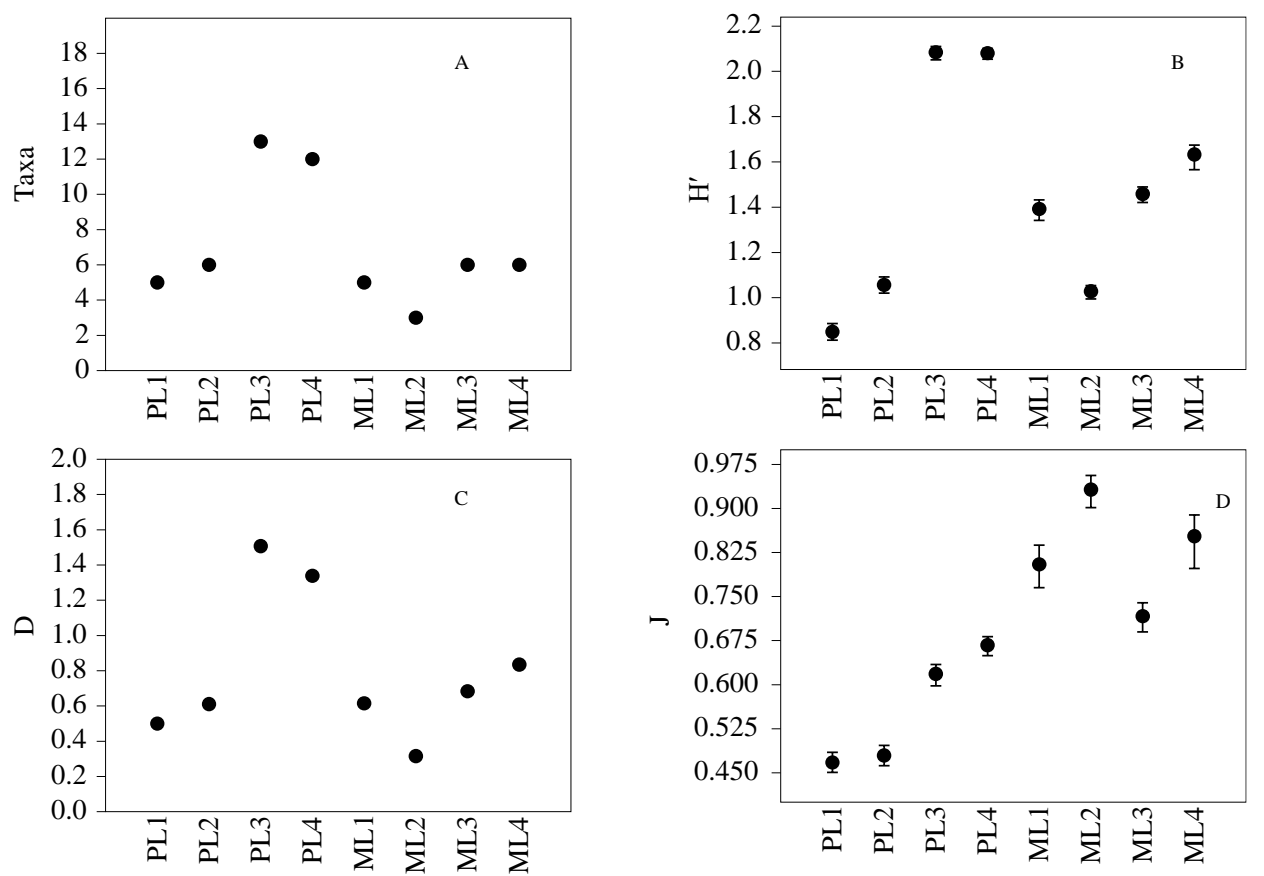

Figure 7. Variability of Polychaete diversity indices in the present study (A: Number of taxa, B: S-W index; C: species richness; D: Evenness index)

It can be summarized from this study that; shipbreaking activities had a greater impact on the macrobenthos community. Abundance, number of taxa, diversity index, and species richness were higher in the non-ship-breaking area than the ship-breaking area. Besides, the Polychaeta community and several pollution indicator taxa denoted that ship-breaking area was facing contamination which causes the differences with non-shipbreaking area. Therefore, we hypothesize that there might be some pollution like metal concentration, or petroleum hydrocarbon, or organic matter which was responsible for the decrease of macrobenthos in the ship-breaking area. Rainfall might have a positive influence on the reduction of detrimental impacts on the impacted site. However, further research is recommended to know the comprehensive impact of ship-breaking (organic and inorganic pollution) on macrobenthos in this area.

\section{REFERENCES}

Abdullah HM, Mahboob MG, Banu MR, Seker DZ. 2013. Monitoring the drastic growth of ship-breaking yards in Sitakunda: A threat to the coastal environment of Bangladesh. Environ Monit Assess 185 (5): 3839-3851. DOI: $10.1007 / \mathrm{s} 10661-012-2833-4$

Abu Hena MK, Sidik JB, Aysha A, Ahasan H, Short FT. 2013. Estuarine macrophytes at Bakkhali, Cox's Bazar, Bangladesh with reference to mangrove diversity. Chiang Mai J Sci 40 (4): 556-563.

Al-Yamani FY, Skryabin V, Boltachova N, Revkov NK, Makarov M, Grintsov V, Kolesnikova E. 2012. Illustrated Atlas on the Zoobenthos of Kuwait. Kuwait Institute for Scientific Research, Safat, Kuwait.

Apeti DA, Whitall DR, Pait AS, Dieppa A, Zitello AG, Lauenstein GG. 2012. Characterization of land-based sources of pollution in Jobos Bay, Puerto Rico: Status of heavy metal concentration in bed sediment. Environ Monit Assess 184: 811-830. DOI: 10.1007/s10661-011-2003-0.

Asadujjaman M, Hossain MB, Shamsuddin M, Amin MA, Azam AKM. 2012. Occurrence and abundance of macrobenthos of Hatiya and Nijhum Dweep Islands, Bangladesh. Middle-East J Sci Res 11 (2): 184-188.

Belan T. 2003. Benthos abundance pattern and species composition in conditions of pollution in Amursky Bay (the Peter the Great Bay, the Sea of Japan). Mar poll Bull 46: 1111-1119.

Belan TA. 2013. Peculiarities of distribution of taxocenes of polychaete worms (Polychaeta) in Amursky Bay (the Sea of Japan) in the early 21 st century. Pacific Oceanography 6: 64-71.

Chen S, Chen B, Fath BD. 2013. Ecological risk assessment on the system scale: A review of state-of-the-art models and future perspectives. Ecol Modell 250: 25-33. DOI: 10.1016/j.ecolmodel.2012.10.015

Dean HK. 2008. The use of polychaetes (Annelida) as indicator species of marine pollution: A review. Rev Biol Trop 56: 11-38. DOI: 10.15517/RBT.V56I4.27162.

Gogina M, Zettler ML. 2010. Diversity and distribution of benthic macrofauna in the Baltic Sea: Data inventory and its use for species distribution modeling and prediction. J Sea Res 64 (3): 313-321. DOI: 10.1016/j.seares.2010.04.005

Gray JS, Elliott M. 2009. Ecology of Marine Sediments: From Science to Management. Oxford University Press, United Kingdom.

Herman PMJ, Middelburg JJ, Van de Koppel J, Heip CHR. 1999. Ecology of estuarine macrobenthos. Adv Ecol Res 29: 195-240. DOI: 10.1016/S0065-2504(08)60194-4

Hossain MB, Amin SMN, Asadujjaman M, Rahman S. 2013. Analyses of macrobenthos of Hatiya and Nijhum Dweep Islands at higher taxonomic resolution. J Fish Aquat Sci 8 (4): 526-534. DOI: $10.3923 /$ jfas.2013.526.534

Hossain MB. 2009. Polychaete faunal diversity of the Meghna River estuarine bed. Bangladesh J Prog Sci Tech 7 (2): 275-278.

Hossain MK, Hossain SM, Azim R, Meaze AKMMH. 2010. Assessment of radiological contamination of soils due to ship-breaking using HPGe digital gamma-ray spectrometry system. J Environ Prot 1: 1014. DOI: $10.4236 /$ jep. 2010.11002

Hossain MM, Islam MM. 2006. Ship-breaking activities and its impact on the coastal zone of Chittagong, Bangladesh: Towards sustainable 
management. Young Power in Social Action (YPSA), Chittagong, Bangladesh. http://www.ypsa.org/publications/

Islam MS, Sikde MNA, Al-Imran M, Hossain MB, Mallick D, Morshed MM. 2013. Intertidal macrobenthic fauna of the Karnafuli estuary: Relations with environmental variables. World Appl Sci J 21 (9): 1366-1373.

Khan AN, Kamal D, Mahmud MM, Rahman MA, Hossain MA. 2007. Diversity, distribution and abundance of benthos in Mouri River, Khulna, Bangladesh. Int J Sustain Crop Prod 2 (5): 19-23.

Khan A, Manokaran S, Lyla S. 2017. Changes in microbenthic community structure from estuary to continental slope in the southeast coast of India. J Mar Biol Assoc UK 97 (1): 161-180. DOI: $10.1017 / \mathrm{S} 0025315416000229$.

Kumar PS, Khan AB. 2013. The distribution and diversity of benthic macroinvertebrate fauna in Pondicherry mangroves, India. Aqua Biosyst 9: 15. DOI: 10.1186/2046-9063-9-15.

Li X, Zhang Y, Guo F, Gao X, Wang Y. 2018. Predicting the effect of land use and climate change on stream macroinvertebrates based on the linkage between structural equation modeling and Bayesian network. Ecol Indic 85: 820-831.

Lin Q, Zhang Y, Marrs R, Sekar R, Luo X, Wu N. 2020. Evaluating ecosystem functioning following river restoration: The role of hydromorphology, bacteria, and macroinvertebrates. Sci Total Environ 743: 140583. DOI: 10.1016/j.scitotenv.2020.140583

Margalef R. 1958. Information Theory in Biology. General Systems Yearbook, New York.

Mulik J, Sukumaran S, Srinivas T. 2020. Factors structuring spatiotemporal dynamics of macrobenthic communities of three differently modified tropical estuaries. Mar Pollut Bull 150: 110767. DOI: 10.1016/j.marpolbul.2019.110767

NCSG. 2011. S\&P Monthly reports of N. Cotzias shipping group. Accessed from: http://www.cotzias.gr.

Netto SA, Pagliosa PR, Colling A, Fonseca AL, Brauko KM. 2018 Benthic estuarine assemblages from the southern Brazilian marine ecoregion. Brazilian Estuaries Springer, Cham. DOI: 10.1007/978-3319-77779-5_6
Noman MA, Mamunur R, Islam MS, Hossain MB. 2018. Spatial and seasonal distribution of Intertidal Macrobenthos with their biomass and functional feeding guilds in the Naf River estuary, Bangladesh. J Oceanol Limnol 37 (3): 1010-1023. DOI: 10.1007/s00343-019-80637

Olsgard F, Brattegard T, Holthe T. 2003. Polychaetes as surrogates for marine biodiversity: Lower taxonomic resolution and indicator groups. Biodivers Conserv 12 (5): 1033-1049. DOI: 10.1023/A: 1022800405253

Pravinkumar M, Murugesan P, Prakash KR, Elumalai V, Viswanathan C, Raffi SM. 2013. Benthic biodiversity in the Pichavaram mangroves, Southeast Coast of India. J Oceanogr Mar Sci 4 (1): 1-11. DOI: 10.5897/JOMS12.004

Rodrigues SK, Abessa DM, Rodrigues APDC, Soares-Gomes A, Freitas CB, Santelli RE, Freire AS, Machado W. 2017. Sediment quality in a metal-contaminated tropical bay assessed with multiple lines of evidence approach. Environ Pollut 228: 265-276. DOI: 10.1016/j.envpol.2017.05.045

Rubaiyat A, Hossain ML, Kristy SJ, Uddin MK. 2013. Ship-breaking yard soil: Safe or harm for seedlings growth. Am J Environ Eng 3 (3): 121129.

Sarker JM, Patwary SAM, Uddin AMMB, Hasan MM, Tanmay MH, Kanungo I, Parvej MR. 2016. Macrobenthic community structure-an approach to assess coastal water pollution in Bangladesh. Fish Aquac J 7: 157 . DOI: 10.4172/2150-3508.1000157

Siddiquee NA. 2004. Impact of Ship-breaking on Marine Fish Diversity of the Bay of Bengal. DFIDSUFER Project, Dhaka, Bangladesh.

Tagliapietra D, Marco S. 2010. Benthic fauna: Collection and identification of macrobenthic invertebrates. NEAR Curriculum in Natural Environmental Science, Terre et Environnement 88: 253-261.

YPSA. 2005. Workers in Ship-breaking Industries: A Base Line Survey of Chittagong, Bangladesh. Young Power in Social Action (YPSA), Chittagong.

YPSA. 2011. Ship-breaking in Bangladesh: Ship-breaking in newspaper. http://www.shipbreakingbd.info/Newspaper_\%20News.html. 